\title{
Mucocutaneous ulcerations as a first sign of methotrexate toxicity
}

\section{Owrzodzenia błony śluzowej i skóry jako pierwszy objaw toksyczności metotreksatu}

\author{
Ravindranath B. Chavan, Vasudha Belgaumkar, Anil P. Gosavi, Nitika Sanjay Deshmukh, Neelam Bhatt, \\ Kopal Agrawal
}

B.J. Government Medical College, Pune, Maharashtra, India

B.J. Government Medical College, Pune, Maharashtra, Indie

Dermatol Rev/Przegl Derm 2021, 108, 74-76 DOI: https://doi.org/l0.51 |4/dr.2021. 105898

We came across a 72-year-old man, who presented with oral intolerance to spicy food with raw areas over the lips and oral cavity and ulcers over pre-existing psoriatic plaques for the last 6 days. Detailed history revealed that he had taken daily doses of methotrexate (MTX) $7.5 \mathrm{mg}$ twice a day without folic acid for 4 days (cumulative dose of $60 \mathrm{mg}$ ), the last dose taken 72 hours before presenting to us; without any proper prescription or instructions by a local practitioner. On examination, he had multiple erosions with haemorrhagic crusts on the lower lip and buccal mucosa (fig. 1) along with erythematous scaly plaques with partially healed ulcers over the extensor aspect of bilateral extremities (PASI 10.2) (fig. 2). A provisional diagnosis of plaque type psoriasis with acute MTX toxicity was made. Haemogram, serum albumin (3.6), serum albumin/globulin ratio (1.6), and liver and renal function tests were normal. Serum MTX level was $0.2 \mu \mathrm{mol} / 1$. We administered intravenous fluids and folinic acid $\left(30 \mathrm{mg} / \mathrm{m}^{2}\right.$ over 2 to 3 hours, 3 doses 6 hourly) within 2 hours of presentation. Serum MTX level after 48 hours of folinic acid therapy was $0.01 \mu \mathrm{mol} / 1$. The mucosal erosions resolved within 3 to 5 days. Considering higher risk of toxicity due to poor compliance and advanced age, the patient was started on tablets of apremilast $30 \mathrm{mg}$ BD along with antacids. The treatment was well tolerated and his PASI score had decreased to 8.4 at the 1-month follow-up.

Acute MTX toxicity presents as maculo-papular rash, pancytopenia, gastrointestinal (GI) mucositis, hepatotoxicity, pulmonary toxicity and acute renal failure. Ulcerations are observed on oral mucosa and skin changes [1]. Mucositis usually appears 3-7 days after MTX administration and precedes onset of fall of leucocyte and platelet counts by several days [2].
W pracy opisano przypadek 72-letniego mężczyzny, który zgłosił objawy nadwrażliwości błony śluzowej jamy ustnej i warg oraz owrzodzenia rozwijające się na podłożu wcześniejszych blaszek łuszczycowych. Objawy te utrzymywały się u chorego od 6 dni. Na podstawie szczegółowego wywiadu ustalono, że pacjent codziennie stosował metotreksat (MTX) w dawce 7,5 mg 2 razy na dobę, bez suplementacji kwasem foliowym, przez $4 \mathrm{dni}$ (łączna dawka $60 \mathrm{mg}$ ). Ostatnią dawkę przyjął 72 godziny przed zgłoszeniem się do poradni. Lek stosowany był bez odpowiedniej recepty ani zaleceń lekarskich dotyczących stosowania. W badaniu przedmiotowym stwierdzono liczne nadżerki ze strupami krwotocznymi na wardze dolnej i nadżerki na błonie śluzowej policzka (ryc. 1), a także rumieniowe, łuszczące się blaszki i częściowo zagojone owrzodzenia na powierzchniach wyprostnych obu kończyn (wskaźnik Psoriasis Area and Severity Index (PASI) 10,2) (ryc. 2). Ustalono wstępne rozpoznanie łuszczycy plackowatej z ostrą toksycznością wywołaną przez MTX. Morfologia krwi, stężenie albuminy w surowicy $(3,6)$, stosunek albuminy do globuliny w surowicy $(1,6)$ oraz wyniki badań czynności wątroby i nerek były prawidłowe. Stężenie MTX w surowicy wynosiło 0,2 $\mu \mathrm{mol} / 1$. W czasie 2 godzin od zgłoszenia pacjentowi podano dożylnie płyny oraz kwas folinowy (w dawce $30 \mathrm{mg} / \mathrm{m}^{2}$ w czasie 2-3 godzin, 3 dawki co 6 godzin). Po 48 godzinach leczenia kwasem folinowym stężenie MTX w osoczu zmniejszyło się do 0,01 $\mu \mathrm{mol} / 1$. Wówczas zakończono leczenie kwasem folinowym. Nadżerki w obrębie błony śluzowej ustąpiły w czasie 3-5 dni. Ze względu na podwyższone ryzyko toksyczności spowodowane niskim stopniem przestrzegania przez pacjenta zaleceń lekarskich oraz jego podeszły wiek wprowadzono leczenie apremilastem $30 \mathrm{mg}$ w tabletkach 2 razy dziennie, w skojarzeniu z lekami zobo- 


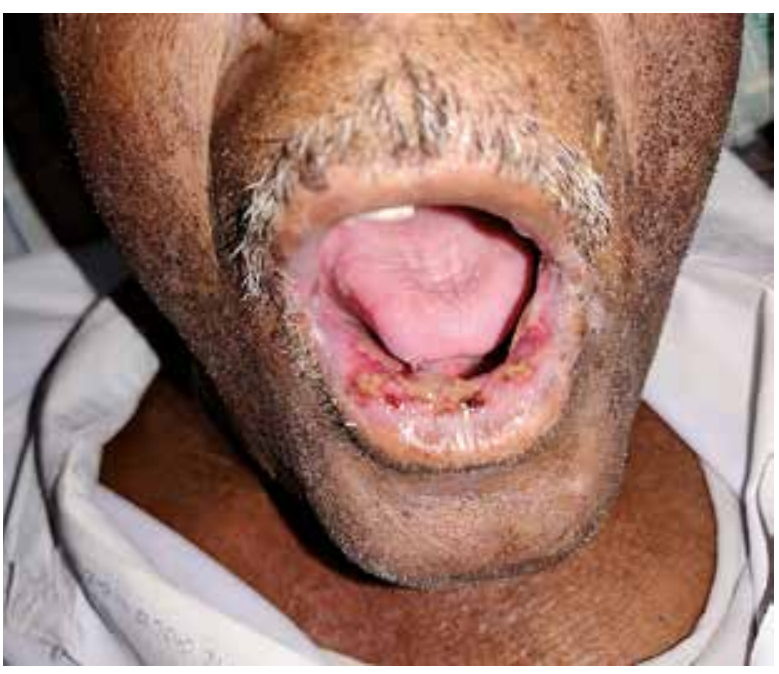

Figure I. Lower lip erosions with haemorrhagic crusts

Rycina I. Nadżerki i strupy krwotoczne w obrębie dolnej wargi

Therefore, prompt identification of this manifestation can facilitate early rescue and preclude progression to serious haematologic alterations [2] by administering injection of folinic acid which bypasses DHFR with direct conversion to tetrahydrofolate (THF). Re-epithelization takes place 1 to 2 weeks after interruption of medication [3]. The most common cause of acute MTX toxicity is an accidental overdose of tablets by the patient or physician's prescription error. The commonest cause of overdose was reported as the quest for a rapid response or permanent cure from psoriasis by self-medication $[4,5]$.

Methotrexate has a good safety profile if used adequate with stringent monitoring. Mucocutaneous manifestations are a warning sign of acute toxicity. In our case, the cause of toxicity (accidental overdose or wrong prescription) was debatable as no prescription was available for scrutiny. This re-emphasises the need for counselling regarding disease chronicity, specific dosing schedule (with maintenance of a diary by literate patients) and consequences of overdosing, particularly in a country such as India where drug regulation is sub-optimal with rampant over-thecounter dispensing and self-medication.

\section{ACKNOWLEDGMENTS}

Departments of Pathology and Biochemistry.

\section{CONFLICT OF INTEREST}

The authors declare no conflict of interest.

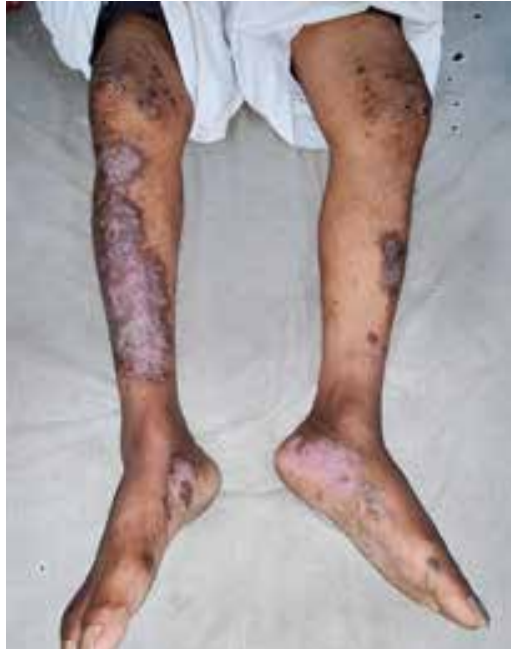

Figure 2. Healing erosions over psoriatic plaques Rycina 2. Gojące się nadżerki na podłożu blaszek łuszczycowych

jętniającymi sok żołądkowy. Leczenie było dobrze tolerowane, a w badaniu kontrolnym po upływie miesiąca wynik pacjenta w skali PASI zmniejszył się do 8,4 punktu.

Objawy ostrej toksyczności MTX obejmują zmiany skórne, pancytopenię, zapalenie błon śluzowych przewodu pokarmowego, hepatotoksyczność, toksyczność płucną oraz ostrą niewydolność nerek. Obserwowane są owrzodzenia umiejscowione na błonie śluzowej jamy i zmianach skórnych [1]. Zapalenie błony śluzowej zwykle rozwija się w czasie 3-7 dni po podaniu MTX i poprzedza o kilka dni zmniejszenie liczby leukocytów i płytek krwi [2]. Szybkie rozpoznanie tego objawu umożliwia odpowiednio wczesne podjęcie działań ratunkowych powstrzymujących rozwój ciężkich zmian hematologicznych [2]. Pacjentowi podaje się dożylnie kwas folinowy, który blokuje działanie DHFR z bezpośrednią konwersją do tetrahydrofolianu (THF). Reepitelializacja następuje 1-2 tygodni po zakończeniu leczenia [3]. Najczęstszą przyczyną ostrych objawów toksycznych MTX jest przypadkowe przedawkowanie leku przez pacjenta lub błąd lekarza przy jego przepisywaniu. Istnieją doniesienia, że najczęstszą przyczyną przedawkowania MTX jest dążenie chorych do osiągnięcia jak najszybszej odpowiedzi na leczenie lub trwałego wyleczenia łuszczycy poprzez podjęcie terapii na własną rękę $[4,5]$.

Metotreksat charakteryzuje się dobrym profilem bezpieczeństwa, jeśli jest właściwie stosowany, a pacjenci są ściśle monitorowani. Zmiany śluzówkowo-skórne stanowią objaw ostrzegawczy zapowiadający wystąpienie ostrych objawów toksycznych po zastosowaniu leku. W naszym przypadku nie było możliwości dokładnego ustalenia przyczyny toksyczności (przypadkowe przedawkowanie czy nieprawidłowo wystawiona recepta) ze względu na brak recepty do wglądu. Opisany przypadek wskazuje jednoznacznie na potrzebę eduko- 
wania pacjentów z łuszczycą w zakresie przewlekłego charakteru choroby, szczegółowego schematu dawkowania (z prowadzeniem dziennika leczenia przez pacjentów potrafiących pisać) i skutków przedawkowania - szczególnie w takim kraju jak Indie, gdzie system regulacji leków jest nieprawidłowy i powszechne jest wydawanie leków bez recepty oraz podejmowanie leczenia na własną rękę.

\section{PODZIĘKOWANIA}

Dziękujemy za pomoc Klinice Patologii i Biochemii.

\section{KONFLIKT INTERESÓW}

Autorzy nie zgłaszają konfliktu interesów.

\section{References}

\section{Piśmiennictwo}

1. Lawrence C.M., Dahl M.G.: Two patterns of skin ulceration induced by methotrexate in patients with psoriasis. J Am Acad Dermatol 1984, 11, 1059-1065.

2. Madke B., Singh A.L.: Acute methotrexate toxicity. Indian J Drugs Dermatol 2015, 1, 46-49.

3. Fridlington J.L., Tripple J.W., Reichenberg J.S., Hall C.S., Diven D.G.: Acute methotrexate toxicity seen as plaque psoriasis ulceration and necrosis: a diagnostic clue. Dermatol Online J 2011, 17, 2.

4. Agarwal K.K., Nath A.K., Thappa D.M.: Methotrexate toxicity presenting as ulceration of psoriatic plaques: a report of two cases. Indian J Dermatol Venereol Leprol 2008, 74, 481-484.

5. Pearce H.P., Wilson B.B.: Erosion of psoriatic plaques: an early sign of methotrexate toxicity. J Am Acad Dermatol 1996, 35, 835-838.

Received: 23.05 .2020

Accepted: 31.07 .2020

Otrzymano: $23.05 .2020 \mathrm{r}$.

Zaakceptowano: $31.07 .2020 \mathrm{r}$.

How to cite this article

Chavan R.B., Belgaumkar V., Gosavi A.P., Deshmukh N.S., Bhatt N., Agrawal K.: Mucocutaneous ulcerations as a first sign of methotrexate toxicity. Dermatol Rev/Przegl Dermatol 2021, 108, 74-76. DOI: https://doi.org/10.5114/dr.2021.105898. 